\title{
SISTEM BAGI HASIL TANAMAN JERUK DESA KEBONDALEM KECAMATAN BANGOREJO KABUPATEN BANYUWANGI
}

\section{Sucii Ristianingsih ${ }^{1}$, Sukidin $^{1}$, Pudjo Suharso ${ }^{1}$}

${ }^{1}$ Program Studi Pendidikan Ekonomi, Fakultas Keguruan dan Ilmu Pendidikan, Universitas Jember e-mail: suciristianingsih@gmail.com

\begin{abstract}
Abstrak
Penelitian ini bertujuan untuk mengetahui sistem bagi hasil tanaman jeruk Desa Kebondalem Kecamatan Bangorejo Kabupaten Banyuwangi dan untuk menjelaskan hubungan sosial petani pemilik dan petani penggarap dalam sistem bagi hasil tanaman jeruk Desa Kebondalem Kecamatan Bangorejo Kabupaten Banyuwangi. Adapun subjek penelitiannya yaitu petani jeruk pemilik dan penggarap yang melakukan bagi hasil sebanyak 325 orang dan informan penelitian yaitu petani jeruk pemilik dan penggarap yang melakukan bagi hasil maro, mertelu, dan merpat. Teknik pengumpulan data yaitu menggunakan metode observasi partisipasi, wawancara mendalam, dokumen dan dokumentasi. Data yang diperoleh dalam penelitian ini akan digunakan metode deskriptif kualitatif. Hasil penelitian menunjukkan bahwa sistem bagi hasil yang banyak digunakan oleh petani jeruk Desa Kebondalem Kecamatan Bangorejo Kabupaten Banyuwangi yaitu bagi hasil maro dan mertelu. Masyarakat Desa Kebondalem Kecamatan Bangorejo dalam memenuhi kebutuhannya kebanyakan bekerja sebagai petani. Namun tidak semua petani memiliki lahan sendiri untuk dikelola, sehingga banyak masyarakat Desa Kebondalem melakukan sistem bagi hasil. Sistem bagi hasil dalam pertanian tanaman jeruk ini bertujuan untuk menunjukkan rasa solidaritas antar petani yaitu saling membantu satu sama lain dan menunjukkan bahwa manusia tidak bisa untuk hidup menyendiri, namun selalu membutuhkan orang lain dalam segala aspek.
\end{abstract}

Kata Kunci: Pilihan Rasional, Sistem Bagi Hasil, Moral Ekonomi, Solidaritas

\section{PENDAHULUAN}

Tanaman hortikultura meliputi tanaman buah-buahan (fruits), sayur-sayuran (vegetables), tanaman berkhasiat obat (medical palants) dan tanaman hias (ornamental plants) termasuk didalamnya tanaman air. Masalah yang penting dari komoditas hortikultura adalah sifat bahannya yang cepat mengalami pembusukan, padahal produk hortikultura bernilai sangat tinggi pada kondisi segar. Kecamatan Bangorejo salah satu yang memiliki potensi hortikultura yang berlimpah di Kabupaten Banyuwangi, hal ini disebabkan oleh keadaan lingkungan (tanah, iklim, ketinggian tempat, suhu) yang dapat mendukung pengembangan hortikultura serta mampu melayani permintaan jeruk sampai keluar daerah.

Desa Kebondalem merupakan salah satu desa yang berada di Kecamatan Bangorejo. Masyarakat petani di Desa Kebondalem sebagian besar masyarakatnya bekerja sebagai petani jeruk. Lahan pertanian yang ada di Desa Kebondalem digunakan sebagai lahan perkebunan jeruk. Awalnya lahan pertanian yang ada di Desa Kebondalem digunakan sebagai lahan persawahan yang ditanami padi. Namun dengan adanya perkembangan jaman, petani mengalihfungsikan menjadi lahan perkebunan jeruk. Lahan perkebunan jeruk yang ada di Desa Kebondalem cukup luas yaitu 70,481 hektar. Tanaman jeruk merupakan tanaman yang diunggulkan di Desa Kebondalem karena mampu memberikan perubahan sosial ekonomi seorang petani jeruk.

Pengelolaan pertanian jeruk oleh petani jeruk yang awalnya menggunakan cara sederhana sudah mulai menggunakan teknologi modern. Teknologi yang dipakai oleh petani jeruk membantu petani jeruk dalam merawat tanaman jeruk agar berbuah berkali-kali. Petani jeruk mendapatkan penyuluhan dari pihak dinas pertanian untuk mengelola jeruk agar lebih menguntungkan dan lebih mudah dalam merawat.

Mayoritas petani jeruk Desa Kebondalem memiliki lahan garapan jeruk kurang dari 2 hektar. Kondisi ini menyebabkan petani jeruk kesulitan dalam mengelola tanaman jeruk sendiri. Tanaman jeruk membutuhkan modal yang tinggi untuk biaya perawatan dan ongkos tenaga kerja. Bantuan yang diberikan oleh pemerintah hanya ada pada satu desa yaitu Desa Bangorejo. Petani jeruk Desa Kebondalem yang tidak mampu mengelola lahan pertanian jeruknya sendiri melakukan sistem bagi hasil. Sistem bagi hasil dilakukan untuk meringankan 
beban pemilik tanah. Adanya sistem bagi hasil membantu petani pemilik dalam mengelola tanaman jeruk dan masih ikut andil dalam pembagian hasil panen jeruk tersebut. Pembagian hasil panen disesuaikan dengan kesepakatan dari pemilik tanah dan penggarap sawah. Kesepakatan yang dilakukan yaitu berdasarkan sistem bagi hasil yang dipilih oleh petani pemilik dan penggarap.

Wahyuningsih (dalam Auliyah\&Wulandari,2017:3) menyatakan bahwa ada tiga cara mekanisme bagi hasil yang umumnya dilakukan, yaitu maro, yang mengharuskan penggarap membeli sendiri bibit, pupuk, dan membayar buruuh tani, serta menyerahkan setengah dari hasil panen kepada pemilik sawah. Pajak atas tanah ini dibayar oleh pemiliknya. Mertelu adalah cara bagi hasil dengan syarat-syarat yang sama dengan maro, tetapi dalam hal ini penggarap sawah hanya menerima sepertiga bagian dari hasilnya. Sedangkan, sistem merpat penggarap hanya memperoleh seperempat bagian dari hasil panen, tetapi ia hanya membayar buruh tani saja.

Menurut ekonomi rasional, para petani melakukan investasi, baik berjangka panjang maupun berjangka pendek, dan dengan demikian mereka melakukan baik investasi berisiko maupun investasi aman. Adapun alternatif investasi yang bisa dipilih oleh petani meliputi dalam bentuk anak, ternak, tanah, dan dalam bentuk benda milik pribadi atau benda milik keluarga, atau dengan cara lain dengan mengeluarkan surplus-surplus produksi mereka melalui desa, pada program-program asuransi atau kesejahteraan, atau melalui perbaikanperbaikan desa, Popkin (dalam Damsar\&Indrayani, 2016:161).

Sistem bagi hasil di Jawa terdiri dari sejumlah besar variasi khusus atas sejumlah kecil tema struktural. Hal itu memungkinkan hampir setiap kasus merupakan kasus yang khusus yang merupakan tanggapan terhadap keadaan yang khusus masing-masing perjanjian, tetapi juga memungkinkan tiap kasus itu merupakan contoh yang konkrit tipe umum yang tegas batasnya. Keluwesan di dalam ketetapan inilah yang menyebabkan bagi hasil itu mempunyai faedah yang khusus sebagai suatu mekanisme involusi (Geertz, 1983 : 103-104).

Ada dua bentuk kombinasi dari sistem bagi garap (bagi hasil) dan sistem garap dengan hasil bumi yang umum dipakai yaitu Pertama, sebelum dilakukan penggarapan, pemilik tanah mendapatkan hasil bumi yang senilai uang sebagai penggantinya. Perbandingan bagi hasil dan bagian masing-masing dalam menyediakan sarana produksi sama seperti sistem maro garap-separuh. Kedua pemilik sebagai satu-satunya penyedia lahan garapan, menuntut dari penggarap mula-mula bagian tertentu sering seperdelapan dari hasil panen. Setelah pengurangan hasil ini, sisanya dibagi di antara mitra kontrak tersebut secara sama. Penggarap untuk pembagian panen ini sering harus menyediakan sendiri semua ongkos yang diperlukan termasuk tenaga kerja (Planck, 1993:163).

Pada tahun 1869 bagi hasil dilakukan dengan cara maro, tetapi dalam tahun 1929 dilakukan dengan cara mertelu bagi tanah sawah yang terbaik dan dengan cara maro bagi sawah yang kurang baik. Dalam sistem mertelu pemberi sakapan menerima 2/3, penyakap/penggarap menerima 1/3 bagian dari hasil (Tjondronegoro \& Wiradi, 2008:112). Menurut Maliki (2004:87) menyatakan bahwa masyarakat desa cenderung memiliki solidaritas sosial yang kuat. Solidaritas sosial ini didasarkan atas kesamaan menciptakan hubungan informal, masyarakat bersifat komunal atau "guyub”. Sehingga masyarakat desa cenderung memiliki solidaritas mekanik. Durkheim membagi solidaritas sosial menjadi dua yaitu solidaritas mekanik dan solidaritas organik. Solidaritas Mekanik yaitu solidaritas yang berdasarkan tali ikatan tradisional. Solidaritas Organik yaitu masyarakat yang berkembang atas dasar pembagian kerja.

Menurut pandangan ekonomi moral petani umumnya tidak memiliki sikap manusia rasional yang berusaha memaksimalkan, melainkan lebih memiliki sikap yang lebih mementingkan keselamatan karena sifat pertanian mereka yang subsisten itu pula, kadang-kadang petani enggan mengadopsi inovasi baru. Misalnya, mereka takut menggunakan bibit baru dan tetap menggunakan bibit lokal yang tidak unggul, sebab jika eksperimen ini tidak berhasil atau panen gagal, kehidupan mereka bisa terancam karena tidak ada yang dimakan (Deliarnov, 2006:154).

Berdasarkan pemaparan di atas, maka peneliti bermaksud mengadakan penelitian yang bertujuan untuk mengetahui sistem bagi hasil tanaman jeruk Desa Kebondalem Kecamatan Bangorejo Kabupaten Banyuwangi dan untuk menjelaskan hubungan sosial petani pemilik dan penggarap dalam sistem bagi hasil tanaman jeruk Desa Kebondalem Kecamatan Bangorejo Kabupaten Banyuwangi. 


\section{METODE PENELITIAN}

Penelitian ini dilakukan dengan metode deskriptif kualitatif. Adapun metode penentuan lokasi penelitian yaitu di Desa Kebondalem Lecamatan Bangorejo Kabupaten Banyuwangi, dengan subjek penelitian yaitu petani pemilik dan penggarap yang melakukan bagi hasil berjumlah 325 dan informan penelitiannya yaitu petani pemilik dan penggarap yang melakukan bagi hasil maro, mertelu, merpat. Metode pengumpulan data menggunakan observasi partisipasi, wawancara mendalam, dokumen, dan dokumentasi. Analisis data menggunakan model Miles and Huberman dalam Usman dan Purnomo (2009:85-88) yaitu Data Reduction (Reduksi Data), Data Display (Penyajian Data), dan Conclusion Drawing/Verification.

\section{HASIL DAN PEMBAHASAN}

\section{Hasil Penelitian}

Petani pemilik dan petani penggarap dalam melakukan bagi hasil mempertimbangkan keuntungan dan kerugian yang akan didapatkan. Petani pemilik tanah yang memiliki tanah kosong mencari petani penggarap untuk mengerjakan lahan mereka yang kosong. Petani penggarap yang dipilih merupakan orang yang benarbenar mampu untuk melakukan bagi hasil. Bagi hasil yang dilakukan petani pemilik dan petani penggarap perlu adanya kesepakatan terlebih dahulu. Kesepakatan yang dibuat antara petani pemilik dan petani penggarap berupa bagi hasil mana yang akan memberikan keuntungan dari kedua pihak. Adanya bagi hasil memberikan peluang kepada petani penggarap untuk mengelola lahan kososng untuk ditanami jeruk, sedangkan petani pemilik membutuhkan penggarap untuk mengelola lahannya yang kosong.

Desa Kebondalem Kecamatan Bangorejo Kabupaten Banyuwangi masyarakatnya yang mayoritas petani jeruk, namun juga masih ada petani yang tidak menanam jeruk. Jeruk merupakan tanaman yang diunggulkan oleh masyarakat desa Kebondalem. Meskipun jeruk memerlukan biaya perawatan dan ongkos tenaga kerja yang cukup mahal namun jeruk tetap diminati masyarakat. Jeruk merupakan tanaman jangka panjang yang hasil panen buahnya memberikan hasil yang maksimal dibandingkan dengan tanaman padi. Petani jeruk lebih memilih bagi hasil karena hasilnya bisa setiap panen.

Jeruk merupakan tanaman tahunan yang berjangka panjang dan memiliki nilai jual yang tinggi. Masa tanam jeruk dari mulai bibit sampai panen pertama berjarak 2 tahun. Untuk selanjutnya jeruk panen 7 bulan sekali. Jeruk membutuhkan biaya perawatan yang cukup banyak mulai dari pupuk, obat, dan pengairan sawahnya. Sebelum jeruk panen mulai dari bibit disamping dan dibawah tanaman jeruk akan ditanami padi. Setelah padi, bisa juga ditanami jagung, maupun cabai. Jeruk yang sudah berumur 2 tahun sudah tinggi dan dibawah tanaman jeruk sulit untuk ditanami tanaman lain karena akan menggangu pertumbuhan tanaman jeruk, sehingga setelah 2 tahun perawatan memfokuskan pada tanaman jeruk.

Pembagian hasil untuk tanaman jeruk maro bagian hasil panen sama dibagi dua. Sedangkan untuk mertelu pembagian hasil untuk pemilik 1 dan penggarap 2. Untuk pengeluaran biaya pada sistem maro yaitu semua biaya ditanggung bersama mulai dari bibit, perawatan dan obat semuanya ditanggung bersama. Sedangkan untuk mertelu biaya perawatan mulai dari bibit dan obat semuanya ditanggung penggarap, pemilik hanya memberikan lahan saja.

Bagi hasil sering digunakan oleh petani jeruk Desa Kebondalem Kecamatan Bangorejo karena tidak mampu mengerjakan sendiri. Penggarap lahan biasanya dipilih oleh pemilik tanah sendiri karena pemilik mempercayakan lahannya untuk diolah dengan bagus. Pemilik memilih penggaraap yang rajin dan dapat dipercaya, namun juga memilih anggota keluarga untuk menggarap lahannya karena jika digarap oleh keluarga sendiri akan lebih mudah dalam komunikasi. Penggarap yang dipilih pemilik merupakan tetangga sendiri karena mengetahui aktivitas dan karakternya setiap hari. Jadi untuk bagi hasil yang dilakukan antara pemilik tanah dan penggarap lebih akrab.

Sistem bagi hasil maro sudah dikenal masyarakat pedesaan dari dulu. Bagi hasil sudah menjadi tradisi dan adat dalam masyrakat pedesaan. Bagi hasil maro juga dilakukan pada tanaman jeruk yang merupakan tanaman tahunan. Tanaman jeruk lebih ringan jika dibagi hasilkan maro karena biaya perawatan jeruk cukup mahal. Mulai dari bibit hingga pupuk dan obat semuanya mahal, sehingga akan lebih mudah jika jeruk dibagi hasilkan. Jika menggunakan bagi hasil maro biaya akan dibagi dua antara petani pemilik dengan petani penggarap. Hasil panen juga dibagi dua sama karena biaya dibagi sama rata. 
Bagi hasil mertelu menjadi pilihan dari seorang pemilik lahan karena semua tanggungan dibebankan kepada penggarap. Pemilik akan memilih penggarap yang dianggap mampu untuk mengerjakan lahan yang dimilikinya. Mertelu dilakukan pada tanaman jeruk karena dianggap hasil panen dari tanaman jeruk menguntungkan. Mertelu dilakukan oleh pemilik dan penggarap atas kesepakatan awal kedua belah pihak. Hasil dari mertelu yaitu pemilik mendapatkan 1 dan penggarap mendapatkan 2 . Hal tersebut terjadi karena pemilik tidak mengeluarkan biaya apapun, namun penggarap yang menanggung keseluruhan biaya mulai dari benih hingga pupuk dan obat.

Bagi hasil dilakukan oleh dua belah pihak yaitu pemilik sawah dan penggarap, di antara keduanya ada suatu persetujuan bersama dan kesepakatan bersama sehingga terjadilah suatu perjanjian bagi hasil, bagi hasil yang dilakukan ternyata tidak hanya menguntungkan materi semata, tetapi dengan kesepakatan yang dilakukan juga dapat meningkatkan suatu solidaritas organik yang menurut Durkheim didasarkan pada tingkat ketergantungan yang tinggi di antara para pelakunya, dalam hal ini pemilik sawah dan penggarap sawah tersebut. Bagi hasil tanaman jeruk di Desa Kebondalem Kecamatan Bangorejo Kabupaten Banyuwangi di dorong oleh beberapa alasan. Selain untuk memberikan peluang kepada orang yang tidak mempunyai sawah sehingga bisa menggarap sawah, juga para pemilik sawah yang sudah tidak sanggup untuk mengolah sawahnya, sehingga tetap menghasilkan hasil panen dari proses bagi hasil.

Petani pemilik dalam melakukan bagi hasil memilih petani penggarap berdasarakan saling membutuhkan. Saling membutuhkan tersebut bisa terjadi kesepakatan untuk melakukan bagi hasil. Petani pemilik melakukan kesepakatan dengan petani penggarap karena petani pemilik melihat pekerjaan yang dilakukan oleh petani penggarap sangat terampil, sehingga petani pemilik memilih penggarap terssebut. Selain karena keterampilan petani pemilik juga melihat dari hubungan sosial, yaitu berupa saudara dan kerabat dekat. Petani pemilik memilih kerabat karena alasannya agar lahan yang dibagi hasilkan tidak diolah orang lain dan agar ekonomi kerabatnya setara dengan petani pemilik atau bahkan bisa lebih. Petani pemilik memilih bagi hasil yang digunakan sesuai dengan kondisi ekonomi yang ada pada petani penggarap. Jika petani penggarap memiliki pekerjaan sampingan biasanya lebih memilih menggunakan merteu,namun jika petani penggarap kurang mampu maka menggunakan maro.

\section{Pembahasan}

Masyarakat Desa Kebondalem Kecamatan Bangorejo dalam memenuhi kebutuhannya kebanyakan bekerja sebagai petani. Namun tidak semua petani memiliki lahan sendiri untuk dikelola, sehingga banyak masyarakat Desa Kebondalem melakukan sistem bagi hasil. Bagi hasil yang dilakukan masyarakat Desa Kebondalem merupakan tanaman jeruk. Tanaman jeruk dibagi hasilkan dengan sistem maro dan mertelu. Masyarakat petani jeruk lebih memilih kedua sistem tersebut karena dianggap lebih ringan.

Kesepakatan yang dibuat antara pihak petani pemilik dengan petani penggarap dilakukan secara lisan dengan musyawarah untuk mufakat diantara kedua belah pihak tanpa menghadirkan saksi. Petani pemilik dengan petani penggarap sudah saling percaya sehingga keduanya tidak ada keraguan untuk melakukan kesepakatan bagi hasil. Kedua belah pihak melakukan bagi hasil karena ada faktor dorongan untuk saling tolong menolong. Petani pemilik tanah dan petani penggarap melakukan kesepakatan bagi hasil dengan cara petani pemilik menyerahkan tanahnya untuk digarap oleh penggarap dan nanti hasil dari panen tanaman yang ada di tanah tersebut dibagi sesuai dengan hak yang diterima. Sejalan dengan yang diungkapkan oleh Ilyas (2011:107) bahwa bagi hasil merupakan suatu perjanjian yang menyangkut tanah, di mana pemilik menyerahkan tanahnya untuk digarap orang lain dengan kewajiban bagi penggarap menyerahkan sebagian hasil kepada pemilik menurut perimbangan yang telah disepakati. Pemilik disamping sebagai pemegang hak atas tanah juga berhak atas bagian hasil sedangkan penggarap hanya berhak atas bagian hasil dari tanah yang digarapnya.

Sistem bagi hasil tanaman jeruk di Desa Kebondalem Kecamatan Bangorejo merupakan bagi hasil yang merupakan tanaman tahunan. Jeruk mampu bertahan hidup hingga 8 tahun dengan perawatan yang tepat. Jeruk merupakan tanaman yang membutuhkan perawatan dengan biaya yang mahal. Mulai dari benih hingga pupuk dan obat semuanya membutuhkan biaya yang mahal. Jeruk mulai berbuah pada tahun ketiga, sehingga 2 tahun dari awal pembibitan masih belum bisa dipanen. Setelah 2 tahun jeruk berbuah 7 bulan sekali bisa dipanen. 
Petani pemilik pada penelitian ini memilih petani penggarap dan kemudian petani pemilik menentukan sistem apa yang dilakukan untuk kesepakatan bagi hasil. Kemudian petani pemilik dan penggarap bersepakat untuk memilih sistem maro, karena petani penggarap tidak mampu untuk menggunakan sistem yang lainnya. Untuk tanaman jeruk yang mampu dilakukan yaitu dengan menggunakan maro karena biaya dan hasil nantinya dibagi sama rata. Sistem maro banyak digunakan petani jeruk karena melihat dari biaya perawatan jeruk yang mahal, sehingga jika dibebankan kepada satu orang akan membebani dan juga lahan yang diparokan cukup luas untuk ditanggung satu pihak.

Sistem bagi mertelu juga banyak digunakan oleh petani jeruk Desa Kebondalem Kecamatan Bangorejo. Bagi hasil mertelu dilakukan oleh penggarap yang ekonominya cukup karena bagi hasil mertelu untuk biya keseluruhan ditanggung oleh petani penggarap. Petani pemilik membagi hasilkan dengan cara mertelu jika lahannya tidak begitu luas, sehingga biaya yang dikeluarkan oleh petani penggarap tidak membebani. Sejalan dengan yang dikatakan oleh Planck (1993:164) bahwa sistem mertelu (bagi tiga garapan; bagi tiga hasil) yaitu si pemilik tanah yang menyediakan lahan pertanian mendapat dua pertiga hasil panen karena menyediakan lahan pertanian. Ada juga yang ikut menyediakan bibit. Penggarap yang kebanyakan harus menyediakan sarana produksi dan ongkos usaha lainnya, mendapatkan sepertiga panen.

Saling membantu satu sama lain merupakan suatu hal yang merupakan menunjukkan bahwa manusia tidak bisa untuk hidup menyendiri, namun selalu membutuhkan orang lain dalam segala aspek. Karena setiap orang tidak bisa hidup sendiri, maka seharusnya sebagai makhluk sosial perlu adanya saling memberi petolongan kepada orang yang membutuhkan. Saling tolong menolong merupakan kodrat setiap manusia seperti orang yang kaya perlu untuk memberikan pertolongan kepada yang miskin. Sebagaimana yang diungkapkan oleh Jamaludin (2015:77) bahwa orang desa sangat memegang teguh prinsip gotong royong dan musyawarah untuk mufakat dalam kehidupan sehari-harinya. Antara satu warga dengan warga lain merupakan ikatan keluarga yang harus dibantu dan ditolong. Oleh karena itu, prinsip gotong royong, tolong menolong mewarnai sebagai bagian tradisi dan adat turun-temurun.

Petani pemilik lahan dan petani penggarap merupakan dua pihak yang saling membutuhkan, namun petani pemilik yang memberikan lahan kepada petani penggarap untuk menambah ekonomi keluarga bagi petani penggarap. Satu pihak petani pemilik membutuhkan tenaga dari petani penggarap untuk mengelola lahan agar menghasilkan uang. Pihak penggarap membutuhkan lahan untuk menggarap agar mendapatkan uang dari hasil panen. Kedua pihak tersebut saling membantu untuk mendapatkan keuntungan dan melakukan kesepakatan dalam bagi hasil. Sebagaimana diungkapkan oleh pendapat Latief (2000:256) bahwa gotong royong merupakan bentuk saling menolong yang berlaku di desa-desa Indonesia. Gotong royong juga merupakan bentuk solidaritas khas masyarakat agraris tradisional. Masyarakat-masyarakat ini terikat satu sama lain berdasarkan relasi sosial yang disebut ikatan primordial, yaitu lewat ikatan keluarga, dekatnya letak geografis, serta iman kepercayaan.

Sesuai dengan fakta di lapangan bahwa petani pemilik dalam memberikan garapan lahan memikirkan ikatan keluarga terlebih dahulu. Sebagaimana petani pemilik desa Kebondalem, kebanyakan dari petani pemilik lebih mengutamakan anggota keluarga sendiri yang mengerjakan lahannya drpada diberikan kepada orang lain yang belum tentu dapat dipercaya. Jika keluarga sendiri yang diberikan garapan, maka petani pemilik sudah mengetahui karakter dan sifat orang tersebut dalam aktifitas sehari-hari dan untuk memantau juga lebih mudah karena masih anggota keluarga. Anggota keluarga diutamakan karena agar mampu meningkatkan taraf hidup anggota keluarga. Selain untuk meningkatkan taraf hidup yaitu untuk menjadikan hubungan keluarga menjadi lebih erat tanpa adanya kerenggangan.

\section{KESIMPULAN}

Sistem bagi hasil tanaman jeruk yang dilakukan oleh petani jeruk ada beberapa macam, namun yang sering digunakan dalam perjanjian bagi hasil oleh petani jeruk yaitu bagi hasil maro, dan mertelu. Bagi hasil menjadikan petani jeruk lebih mudah dalam mengelola tanaman jeruk. Kemudahan yang didapatkan oleh petani dalam bagi hasil tanaman jeruk terlihat pada pembiayaan tanaman jeruk. Bagi hasil maro dalam pembiayaan tanaman jeruk ditanggung bersama oleh kedua belah pihak yaitu petani jeruk pemilik lahan dengan petani jeruk penggarap. Hasil panen yang didapatkan juga dibagi sama rata karena keseluruhan biaya ditanggung bersama. Berbeda dengan bagi hasil mertelu yang pembiayaan keseluruhan dilimpahkan kepada petani jeruk penggarap. 
Petani jeruk penggarap membiayai keseluruhan biaya dan hasil panen pembagian yang paling banyak didapatkan oleh petani jeruk penggarap yaitu sebesar 2 bagian, sedangkan petani pemilik lahan mendapatkan 1 bagian saja. Bagi hasil dipilih petani jeruk sesuai dengan kesepakatan bersama dimana dianggap lebih menguntungkan. Bagi hasil dianggap lebih menguntungkan dilihat dari berbagai sisi, yaitu tergantung dari petani jeruk itu sendiri yang memilih bagi hasil yang mana. Petani jeruk melakukan bagi hasil dengan kerabat, tetangga, dan teman.

\section{SARAN}

Sebaiknya sistem bagi hasil pada tanaman jeruk terus dilanjutkan hingga turun temurun untuk menciptakan solidaritas antar petani pemilik dan petani penggarap. Agar mampu menciptakan rasa saling membantu dan gotong royong dalam segala aspek begitu juga dalam aspek pertanian. Jika ada petani yang membutuhkan lahan garapan maka petani pemilik memberikan lahannya untuk dikerjakan dan mendapatkan hasil untuk digunakan dalam keperluan sehari-hari.

\section{DAFTAR PUSTAKA}

Auliyah, Robiatul \& Anis Wulandari. 2017. Potret Bagi Hasil Pertanian. Yogyakarta: Deepublish

Damsar \& Indrayani. 2016. Pengantar Sosiologi Perdesaan. Jakarta : Kencana

Deliarnov. 2006. Ekonomi Politik. Jakarta: Erlangga

Ilyas, Ismail,. 2011. Konsepsi hak Garap Atas Tanah. Bandung : Citapustaka Media Perintis

Jamaludin, Adon Nasrullah. 2015. Sosiologi Perdesaaan. Bandung: CV Pustaka Setia

Planck,Ulrich. 1993. Sosiologi Pertanian. Terjemahan oleh Titi Soentoro dan Suyanto. Jakarta: Yayasan Obor Indonesia.

Usman, Husain dan Purnomo Setiady Akbar. 2009. Metodologi Penelitian Sosial. Jakarta: PT. Bumi Aksara

Latief, Syahbudin M., 2000. Persaingan Calon Kepala Desa di Jawa. Yogyakarta: Media Pressindo 